\title{
The Catabolism of 5-Hydroxyisophthalic Acid by a Soil Bacterium
}

\author{
By ELMORSI A. ELMORSI AND DAVID J. HOPPER \\ Department of Biochemistry, University College of Wales, Aberystwyth, Dyfed, SY23 3DD
}

(Received 11 May 1978)

\begin{abstract}
A bacterium capable of growth on 5-hydroxyisophthalate was isolated from soil. Both 4,5-dihydroxyisophthalate and protocatechuate were found in the growth medium and were also oxidized by bacterial extracts. These extracts catalysed the decarboxylation of 4,5dihydroxyisophthalate to give protocatechuate under anaerobic conditions. Extracts oxidized 5-hydroxyisophthalate only when reduced pyridine nucleotide was present, and did so at a faster rate with NADPH than with NADH. When the decarboxylase was removed by DEAE-cellulose chromatography, 4,5-dihydroxyisophthalate was identified as the product of 5-hydroxyisophthalate oxidation. A pathway for catabolism of 5-hydroxyisophthalate involving hydroxylation to 4,5-dihydroxyisophthalate followed by decarboxylation to protocatechuate, the ring-fission substrate, is proposed. Further oxidation of protocatechuate is by the ortho pathway.
\end{abstract}

\section{INTRODUCTION}

Studies on aromatic dicarboxylic acid metabolism have been chiefly concerned with the catabolism of phthalic acid and its esters. These are used widely as plasticizers and have been found as environmental contaminants (Mayer et al., 1972); the other isomers, isophthalate and terephthalate, are also produced for industrial use. In its metabolism by a Pseudomonas species, phthalic acid loses one of its carboxyl groups prior to ring fission in a pathway involving dihydroxylation of the aromatic ring to give 4,5-dihydroxyphthalic acid followed by decarboxylation (Ribbons \& Evans, 1960). This yields protocatechuic acid, the ringfission substrate for a number of aromatic pathways (Chapman, 1972). The same pathway was proposed by Nakazawa \& Hayashi (1977) for Pseudomonas testosteroni and by Engelhardt et al. (1976) for a number of Gram-positive and Gram-negative organisms. A monohydroxylated acid, 4-hydroxyisophthalic acid, is degraded by Pseudomonas putida, again giving protocatechuic acid but by a single-step oxidative decarboxylation (Elmorsi \& Hopper, 1977). The 4-hydroxyisophthalate itself is formed by oxidation of the methyl groups of 2,4-xylenol (Chapman \& Hopper, 1968). This paper describes the pathway for degradation of the structurally similar compound, 5-hydroxyisophthalic acid, by a soil bacterium. This compound is found in the leaves of the shrub Vitex negundo (Heilbron, 1965). Recently, the formation of a related compound, 4,5-dihydroxyisophthalate, by a Streptomyces species was reported (Endo et al., 1978).

\section{METHODS}

Bacterial strain. Strain $5 \mathrm{HI}$ was isolated from soil by elective culture in liquid medium containing $10 \mathrm{~mm}-$ 5-hydroxyisophthalate as the sole carbon source. It is Gram-positive and may be coccoid or rod-shaped, some of the rods being joined in angular arrangements. It is non-motile, catalase-positive, oxidase-negative, produces acid from glucose oxidatively, and hydrolyses starch and gelatin but not tributyrin or arginine. It grows on Koser's citrate medium and produces nitrite from nitrate, but there is no growth under anaerobic conditions. It was maintained at $4{ }^{\circ} \mathrm{C}$ on nutrient agar slants grown at $30^{\circ} \mathrm{C}$ for $24 \mathrm{~h}$. 
Growth of organism. The growth medium contained (per litre): $\mathrm{Na}_{2} \mathrm{HPO}_{4}, 4.33 \mathrm{~g} ; \mathrm{KH}_{2} \mathrm{PO}_{4}, 2.65 \mathrm{~g} ; \mathrm{NH}_{4} \mathrm{Cl}$, $2.0 \mathrm{~g}$; nitrilotriacetic acid, $0 \cdot 1 \mathrm{~g} ; 5$-hydroxyisophthalic acid, $2 \cdot 0 \mathrm{~g} ; 4 \mathrm{ml}$ salts solution (Rosenberger \& Elsden, 1960); the $\mathrm{pH}$ was adjusted to $7 \cdot 0$ using $0.5 \mathrm{M}-\mathrm{NaOH}$. Organisms were grown in $100 \mathrm{ml}$ medium in $250 \mathrm{ml}$ Erlenmeyer flasks at $30^{\circ} \mathrm{C}$ on an orbital shaker (Gallenkamp; $150 \mathrm{rev} . \mathrm{min}^{-1}$ ), and then inoculated into 11 medium in a 21 Erlenmeyer flask which was incubated in the same way. These cultures were used for Warburg experiments and to inoculate 101 medium in a Microferm MF-114 fermenter (New Brunswick Scientific Co.). The vessel was maintained at $30^{\circ} \mathrm{C}$, aerated at a rate of $41 \mathrm{~min}^{-1}$ and stirred at $150 \mathrm{rev}$. min ${ }^{-1}$. Growth was followed by measuring the turbidity at $540 \mathrm{~nm}$ in a U'nicam SP500 spectrophotometer. The 11 cultures were harvested by centrifuging at $5000 \mathrm{~g}$ for $20 \mathrm{~min}$. The fermenter cultures were harvested using an Alfa Laval LAB 102B continuous flow centrifuge (Alfa Laval Co., Brentford); organisms were washed with $50 \mathrm{~mm}$ phosphate buffer, $\mathrm{pH} 7 \cdot 0$, and, if not used immediately, stored at $-20^{\circ} \mathrm{C}$.

Preparation of bacterial extracts. Frozen suspensions were thawed in 2 vol. $50 \mathrm{~mm}$-phosphate buffer, $\mathrm{pH} 7 \cdot 0$, and bacteria were disrupted by passage through a precooled French pressure cell with a pressure difference at the orifice of $138 \mathrm{MPa}$. Unbroken bacteria and large particulate material were removed by centrifuging at $25000 \mathrm{~g}$ for $30 \mathrm{~min}$ at $2{ }^{\circ} \mathrm{C}$. The supernatant solution was retained and is referred to as crude extract.

Assays. 5-Hydroxyisophthalate-4-hydroxylase was assayed spectrophotometrically at $30^{\circ} \mathrm{C}$ by following the decrease in absorbance at $340 \mathrm{~nm}$ in a $1 \mathrm{~cm}$ light-path cuvette containing (in $1 \mathrm{ml} 50 \mathrm{~mm}$-phosphate buffer, $\mathrm{pH} 7.0$ ) $0.4 \mu \mathrm{mol} 5$-hydroxyisophthalate, $0.2 \mu \mathrm{mol}$ NADPH and enzyme.

4,5-Dihydroxyisophthalate decarboxylase was assayed spectrophotometrically at $30^{\circ} \mathrm{C}$ by following the decrease in absorbance at $307 \mathrm{~nm}$ in a $1 \mathrm{~cm}$ light-path cuvette containing (in $1 \mathrm{ml} 50 \mathrm{~mm}$-phosphate buffer, pH 6.0) $0.16 \mu \mathrm{mol} 4,5$-dihydroxyisophthalate and enzyme. Transformation of $1 \mu \mathrm{mol}$ substrate gave a decrease in absorbance of 2.54 .

Protein was assayed by the method of Gornall et al. (1949) using bovine serum albumin as standard. Elution of protein from a DEAE-cellulose column was followed by measuring the absorbance of fractions at $280 \mathrm{~nm}$.

The presence of 3-oxoadipate in reaction mixtures was demonstrated by the Rothera reaction (Rothera, 1908) and determined manometrically by the method of Sistron \& Stanier (1953).

Spectra. Ultraviolet (u.v.) absorption spectra were recorded with a Unicam SP800 spectrophotometer. For infrared (i.r.) spectra, samples were mulled in Nujol and their spectra were recorded with a Perkin-Elmer Infracord spectrophotometer.

Buffers. Phosphate buffers were prepared by titrating a solution of $\mathrm{KH}_{2} \mathrm{PO}_{4}$ to the required $\mathrm{pH}$ with $0.5 \mathrm{M}-\mathrm{NaOH}$ and diluting to the required concentration.

Chromatography. Thin-layer chromatography (t.l.c.) was carried out on glass plates coated with Kieselgel $\mathrm{GF}_{254}$ (Merck) to a thickness of $0.25 \mathrm{~mm}$ and activated for $30 \mathrm{~min}$ at $110^{\circ} \mathrm{C}$. The following solvents were used: solvent 1, toluene/dioxan/acetic acid $\left(67: 19: 4\right.$, by vol.); solvent 2, petroleum ether (b.p. 60 to $80^{\circ} \mathrm{C}$ )/ ethyl formate/propionic acid (70:30:15.4, by vol.) (Ronkainen, 1963); solvent 3, toluene/acetic acid (8:2, v/v) (Engelhardt et al., 1976); solvent 4, toluene/acetic acid (6:4, v/v). Aromatic compounds were detected by viewing under u.v. light. Phenolic compounds were also detected by spraying with Folin-Ciocalteu reagent and exposing to $\mathrm{NH}_{3}$ (Mitchell \& Davis, 1954) or by spraying with diazotized $p$-nitroaniline (Smith, 1960).

Chemicals. 4,5-Dihydroxyisophthalic acid was prepared from 4-hydroxyisophthalic acid by the method of Hunt et al. (1956). 4-Hydroxy-3-methylbenzoic acid was prepared by the limited biological oxidation of 2,4-xylenol (Chapman \& Hopper, 1968). 3-Hydroxy-4-methylbenzoic acid and 2,3-dihydroxybenzoate were from Aldrich Chemical Co., 5-hydroxyisophthalic acid was from Kodak, and 4-hydroxyisophthalic acid was from ICN Pharmaceuticals. All other aromatic compounds were from BDH. NAD ${ }^{+}, \mathrm{NADP}^{+}$, NADPH, glucose 6-phosphate, glucose-6-phosphate dehydrogenase and alcohol dehydrogenase were from Boehringer.

\section{RESULTS}

\section{Oxidation of compounds by whole bacteria}

The oxidation of the growth substrate and of a number of possible intermediates by strain 5HI grown on 5-hydroxyisophthalate was followed in a Warburg apparatus (Fig. 1). There was no oxidation above the endogenous rate with salicylate, 2,3-dihydroxybenzoate, gentisate (2,5-dihydroxybenzoate), phthalate, isophthalate or terephthalate, and neither these compounds nor those shown in Fig. 1 were oxidized immediately by strain 5HI grown on succinate. 


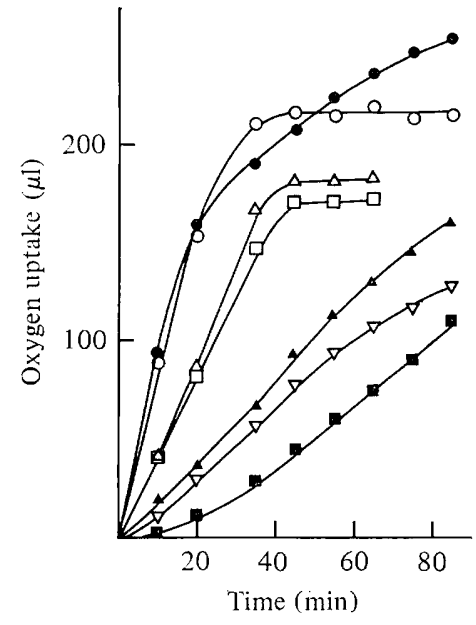

Fig. 1. Oxidation of various compounds by strain $5 \mathrm{HI}$ grown on 5-hydroxyisophthalate. Warburg flasks contained $9 \mathrm{mg}$ dry wt bacteria in $1.5 \mathrm{ml} 50 \mathrm{~mm}$-phosphate buffer, $\mathrm{pH} 7.0,0.3 \mathrm{ml} 10 \mathrm{~mm}-$ substrate tipped from the side-arm and $0.2 \mathrm{ml} 20 \%(\mathrm{w} / \mathrm{v}) \mathrm{KOH}$ in the centre well. Oxygen uptake was measured at $30^{\circ} \mathrm{C}$. The uptake in a flask lacking substrate $\left(60 \mu \mathrm{I} \mathrm{O} \mathrm{h}^{-1}\right)$ has been subtracted. Substrates were: 0 , 5-hydroxyisophthalate; $0,4,5$-dihydroxyisophthalate; $\boldsymbol{\Delta}$, protocatechuate; $\triangle$, 4-hydroxyisophthalate; $\mathbf{\square}, 3$-hydroxybenzoate; $\square$, 4-hydroxybenzoate; $\nabla$, catechol.

\section{Isolation of compounds from the culture filtrate}

During growth of the organism on 5-hydroxyisophthalate, the medium became progressively darker and gave a positive reaction when tested for $o$-dihydric phenols. A 0.51 sample was taken from a 101 culture during the exponential phase of growth and the bacteria were removed by centrifuging. The supernatant solution was reduced to $30 \mathrm{ml}$ by freeze drying and, after acidification to $\mathrm{pH} 2.0$ with $5 \mathrm{M}-\mathrm{HCl}$, was extracted three times with $20 \mathrm{ml}$ diethyl ether. The pooled extracts were dried over anhydrous sodium sulphate and evaporated to dryness yielding $70 \mathrm{mg}$ dark brown residue. This was examined by t.l.c. using solvents 1 and 2 which revealed two spots (compounds $A$ and $B$ ) in addition to the growth substrate. These were separated by preparative t.l.c. using solvent 2 , and the silica gel from the appropriate zones was eluted with $50 \mathrm{~mm}$-phosphate buffer, $\mathrm{pH} 8 \cdot 0$. After centrifuging to remove the gel, the supernatant solution was acidified to $\mathrm{pH} 2.0$ with $5 \mathrm{M}-\mathrm{HCl}$ and extracted several times with diethyl ether. The pooled ether extracts were dried as before and evaporated to dryness giving about $2 \mathrm{mg}$ compound $\mathrm{A}$ and $20 \mathrm{mg}$ compound $\mathrm{B}$. Re-examination by t.1.c. using solvents 1,2, 3 and 4 indicated that compound A corresponded with authentic 4,5-dihydroxyisophthalic acid and compound B with protocatechuic acid. Compound B was recrystallized from water after boiling with charcoal and gave u.v. and i.r. spectra identical with those of authentic protocatechuic acid.

\section{Oxidation of compounds by bacterial extracts}

Crude extracts of strain 5HI grown on 5-hydroxyisophthalate rapidly oxidized 4,5dihydroxyisophthalate and protocatechuate when tested in a Warburg apparatus (Fig. $2 a$ ). No yellow colour was observed during oxidation and the products from both compounds gave a positive Rothera reaction suggesting ortho cleavage of protocatechuate with production of 3-oxoadipate. Catechol was also oxidized by crude extracts, but at a rate only about $15 \%$ of that for protocatechuate. There was no oxidation by crude extracts alone of 5hydroxyisophthalate, 4-hydroxyisophthalate, salicylate, gentisate or 2,3-dihydroxybenzoate. However, when an NADPH-generating system was included, 5-hydroxyisophthalate was rapidly oxidized (Fig. $2 b$ ) and the reaction product again gave a positive Rothera reaction.

The stoicheiometries of $\mathrm{O}_{2}$ uptake, $\mathrm{CO}_{2}$ evolution and 3-oxoadipate production were 


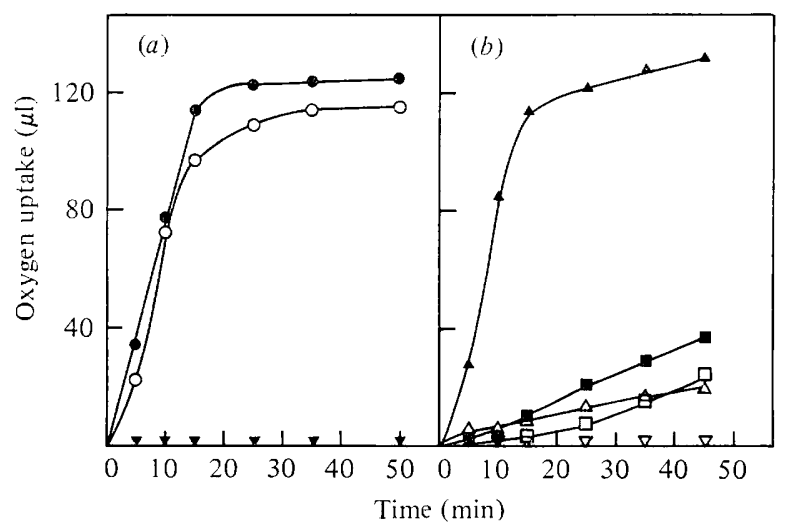

Fig. 2. Oxidation of compounds by bacterial extracts in the absence $(a)$ or presence $(b)$ of reduced pyridine nucleotides. (a) Warburg flasks contained $8.4 \mathrm{mg}$ extract protein (from bacteria grown on 5-hydroxyisophthalate) in $2.5 \mathrm{ml} 50 \mathrm{mM}$-phosphate buffer, pH 7.0, $0.3 \mathrm{ml} 20 \mathrm{mM}$-substrate tipped from the side-arm and $0.2 \mathrm{ml} 20 \%(\mathrm{w} / \mathrm{v}) \mathrm{KOH}$ in the centre well. The temperature was $30^{\circ} \mathrm{C}$. Substrates were: $\boldsymbol{\nabla}, 5$-hydroxyisophthalate; $\bullet$, 4,5-dihydroxyisophthalate; $O$, protocatechuate. Oxygen uptake in the absence of substrate $\left(12 \mu \mathrm{l} \mathrm{h}{ }^{-1}\right)$ has been subtracted. (b) Flasks contained, in addition, either an NADPH-generating system $(1 \mu \mathrm{mol} \mathrm{NADP}+, 10 \mu \mathrm{mol}$ glucose 6 -phosphate and 3 units glucose-6-phosphate dehydrogenase) or an NADH-generating system $\left(1 \mu \mathrm{mol} \mathrm{NAD}{ }^{+}, 20\right.$ $\mu \mathrm{mol}$ ethanol and $0.1 \mathrm{mg}$ alcohol dehydrogenase). Substrates were: $\boldsymbol{\Delta}, 5$-hydroxyisophthalate plus NADPH; $\triangle$, 5-hydroxyisophthalate plus NADH; $\square$, 4-hydroxybenzoate plus NADPH; $\square$, 4-hydroxyisophthalate plus NADPH; $\nabla$, 4-hydroxyisophthalate or 4-hydroxybenzoate plus $\mathrm{NADH}$. Oxygen uptake in the absence of substrate $\left(40 \mu \mathrm{O}_{2} \mathrm{~h}^{-1}\right.$ for NADH; $11 \mu \mathrm{l} \mathrm{O} \mathrm{O}_{2} \mathrm{~h}^{-1}$ for NADPH) has been subtracted.

\section{Table 1. Stoicheiometries of oxidations by bacterial extracts}

Warburg flasks contained $9 \mathrm{mg}$ crude extract protein (from bacteria grown on 5-hydroxyisophthalate) in $2.5 \mathrm{ml} 50 \mathrm{~mm}$-phosphate buffer, $\mathrm{pH} 7.0,0.3 \mathrm{ml}$ substrate tipped from a side-arm and either $0.2 \mathrm{ml} 20 \%(\mathrm{w} / \mathrm{v}) \mathrm{KOH}$ in the centre well for $\mathrm{O}_{2}$ uptake measurements, or $0.2 \mathrm{ml} 2.5 \mathrm{M}-\mathrm{HCl}$, tipped from a second side-arm after completion of reaction, for $\mathrm{CO}_{2}$ evolution measurements. For 5-hydroxyisophthalate oxidation, the mixture also included $2 \mu$ mol NADP,$+ 40 \mu \mathrm{mol}$ glucose 6 phosphate and 3.5 units glucose-6-phosphate dehydrogenase. 3-Oxoadipate was determined manometrically by catalytic decarboxylation using 4-aminoantipyrine (Sistrom \& Stanier, 1953). The temperature was $30^{\circ} \mathrm{C}$. Corrections were made for gas exchanges occurring in control flasks lacking aromatic substrates.

$\begin{array}{lccccc}\text { Substrate } & \begin{array}{c}\mathrm{A} \\ \text { Sub- } \\ \text { strate } \\ \text { added } \\ (\mu \mathrm{mol})\end{array} & \begin{array}{c}\mathrm{B} \\ \begin{array}{c}\mathrm{O}_{2} \\ \text { consumed } \\ (\mu \mathrm{mol})\end{array}\end{array} & \begin{array}{c}\mathrm{C} \\ \mathrm{CO}_{2} \\ \text { evolved } \\ (\mu \mathrm{mol})\end{array} & \begin{array}{c}\mathrm{D} \\ \text { 3-Oxo- } \\ \text { adipate } \\ \text { produced } \\ (\mu \mathrm{mol})\end{array} & \begin{array}{c}\text { Molar ratio } \\ \mathrm{A}: \mathrm{B}: \mathrm{C}: \mathrm{D}\end{array} \\ \text { 5-Hydroxyisophthalate } & 3 & 5 \cdot 6 & 5 \cdot 5 & 2 \cdot 59 & 1: 1 \cdot 87: 1 \cdot 83: 0 \cdot 86 \\ & 6 & 11 \cdot 7 & 12 \cdot 1 & 5 \cdot 54 & 1: 1 \cdot 95: 2 \cdot 01: 0 \cdot 92 \\ \text { 4,5-Dihydroxyisophthalate } & 3 & 2 \cdot 64 & 5 \cdot 98 & 2 \cdot 9 & 1: 0 \cdot 88: 1 \cdot 99: 0 \cdot 97 \\ & 6 & 5 \cdot 94 & 12 \cdot 4 & 5 \cdot 5 & 1: 0 \cdot 99: 2 \cdot 06: 0 \cdot 92 \\ \text { Protocatechuate } & 3 & 2 \cdot 55 & 2 \cdot 55 & 2 \cdot 59 & 1: 0 \cdot 85: 0 \cdot 85: 0 \cdot 86 \\ & 6 & 5 \cdot 54 & 5 \cdot 4 & 5 \cdot 4 & 1: 0 \cdot 92: 0 \cdot 9: 0 \cdot 9\end{array}$

measured manometrically (Table 1). The stoicheiometry of NADPH oxidation was measured spectrophotometrically (Table 2).

\section{Conversion of 4,5-dihydroxyisophthalate to protocatechuate}

When a reaction mixture containing $0.03 \mu \mathrm{mol} 4,5$-dihydroxyisophthalate and $90 \mu \mathrm{g}$

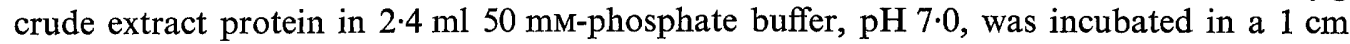
path-length cuvette under anaerobic conditions, the u.v. absorption spectrum of the substrate changed with time to give a spectrum identical with that for an equivalent con- 


\section{Table 2. Stoicheiometry of NADPH utilization during 5-hydroxyisophthalate oxidation by bacterial extracts}

The decrease in $A_{340}$ at $30^{\circ} \mathrm{C}$ was measured when substrate was added to a $1 \mathrm{~cm}$ light-path cuvette containing (in $1.0 \mathrm{ml} 50 \mathrm{~mm}$-phosphate buffer, $\mathrm{pH} \mathrm{7.0)} 0.45 \mathrm{mg}$ crude extract protein from bacteria grown on 5-hydroxyisophthalate and $0.2 \mu \mathrm{mol}$ NADPH. The change in absorbance was related to the amount of NADPH utilized using a millimolar absorption coefficient of $6 \cdot 22$.

$\begin{array}{ccc}\begin{array}{c}\text { 5-Hydroxy- } \\ \text { isophthalate } \\ \text { (nmol) }\end{array} & \begin{array}{c}\text { NADPH } \\ \text { oxidized } \\ \text { (nmol) }\end{array} & \begin{array}{c}\text { Ratio } \\ \text { Substrate:NADPH }\end{array} \\ 50 & 45 & 1: 0 \cdot 9 \\ 100 & 90 & 1: 0.9 \\ 150 & 138 & 1: 0.92\end{array}$

centration of protocatechuic acid. The major changes were the loss of a peak at $308 \mathrm{~nm}$ and the appearance of a peak at $289 \mathrm{~nm}$. When no further change in the spectrum was observed, the cuvette contents were heated to $100{ }^{\circ} \mathrm{C}$ for $5 \mathrm{~min}$ and centrifuged at $15000 \mathrm{~g}$ for $20 \mathrm{~min}$. The supernatant solution was acidified to $\mathrm{pH} 2.0$ with $2.5 \mathrm{M}-\mathrm{HCl}$ and extracted three times with $5 \mathrm{ml}$ diethyl ether. The pooled extracts were dried over anhydrous sodium sulphate and evaporated to dryness. The residue was identical with protocatechuic acid when examined by t.l.c. using solvents $1,2,3$ and 4 .

\section{Separation of hydroxylase and decarboxylase activities}

Extracts of 5-hydroxyisophthalate-grown bacteria contained 5-hydroxyisophthalate

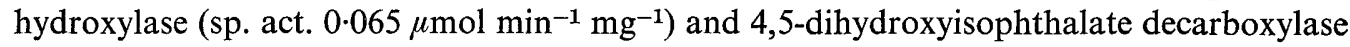
(sp. act. $0.57 \mu \mathrm{mol} \mathrm{min}^{-1} \mathrm{mg}^{-1}$ ) activities. Neither activity was present in succinate-grown bacteria. The two activities were separated by chromatography on a DEAE-cellulose column. Crude extract $\left(50 \mathrm{ml}\right.$ containing $9 \mathrm{mg}$ protein $\mathrm{ml}^{-1}$ ) was loaded on to a DEAE-cellulose column $(16 \times 2.5 \mathrm{~cm})$ equilibrated with $15 \mathrm{~mm}$-phosphate buffer, pH $7 \cdot 1$, at $4{ }^{\circ} \mathrm{C}$. The column was washed with $100 \mathrm{ml}$ of this buffer and the enzymes were eluted by a linear gradient from 0 to $0.6 \mathrm{M}-\mathrm{KCl}$ in $500 \mathrm{ml}$ buffer. Fractions of $6.6 \mathrm{ml}$ were collected and assayed for each enzyme and for protein. The elution profile is shown in Fig. 3. Fractions 35 to 47, containing the hydroxylase activity, were pooled and the protein was concentrated by addition of solid $\left(\mathrm{NH}_{4}\right)_{2} \mathrm{SO}_{4}$ to $70 \%$ saturation. The precipitated protein was collected by centrifuging at

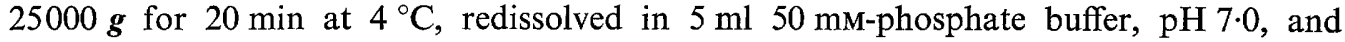
dialysed at $4{ }^{\circ} \mathrm{C}$ against 21 of the same buffer.

When the enzyme was assayed spectrophotometrically only 5-hydroxyisophthalate served as substrate out of a range of aromatic compounds tested, including 4-hydroxyisophthalate, isophthalate, terephthalate, salicylate, 3-hydroxybenzoate, 4-hydroxybenzoate, 2,3-dihydroxybenzoate, 2,5-dihydroxybenzoate, 3,4-dihydroxybenzoate, 3,5-dihydroxybenzoate, 4,5-dihydroxyisophthalate, $m$-toluate, 3-hydroxy-4-methylbenzoate, 3-methyl-4-hydroxybenzoate and 5-sulphosalicylate. The product of the reaction was identified after incubation of $5 \mathrm{ml}$ of partially purified enzyme (16 $\mathrm{mg}$ protein $\left.\mathrm{ml}^{-1}\right)$ with $2 \mathrm{ml} 20 \mathrm{~mm}$-5-hydroxyisophthalate, $10 \mu \mathrm{mol} \mathrm{NADP}+, 200 \mu \mathrm{mol}$ glucose 6-phosphate and 20 units glucose-6-phosphate dehydrogenase for $60 \mathrm{~min}$ at $30^{\circ} \mathrm{C}$. The mixture was acidified to $\mathrm{pH} 2.0$ with $5 \mathrm{M}-\mathrm{HCl}$ and centrifuged at $20000 \mathrm{~g}$ for $20 \mathrm{~min}$. The supernatant solution was extracted three times with $30 \mathrm{ml}$ diethyl ether and the pooled extracts were dried over anhydrous sodium sulphate before evaporation to dryness. Chromatography of the residue by t.1.c. using solvents $1,2,3$ and 4 gave one major spot corresponding with 4,5-dihydroxyisophthalate with a trace of protocatechuate. The u.v. spectrum of the product was very similar to that of 4,5-dihydroxyisophthalate.

The activity of the decarboxylase was demonstrated by following the change in the 


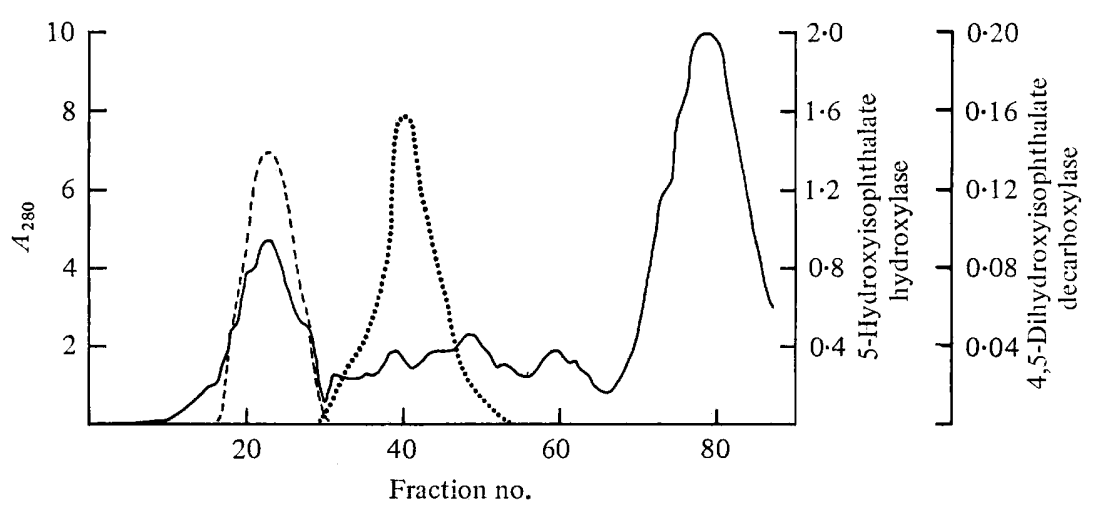

Fig. 3. Separation of 5-hydroxyisophthalate hydroxylase ( $\cdots$, expressed as units per fraction) and 4,5-dihydroxyisophthalate decarboxylase (---, expressed as $\Delta A_{307} \mathrm{~min}^{-1}$ ) by DEAE-cellulose chromatography. Elution of protein was followed by measuring the absorbance at $280 \mathrm{~nm}(\longrightarrow)$.

substrate's spectrum with time when enzyme was added to a solution of 4,5-dihydroxyisophthalate. There was no activity apparent with salicylate, 2,3-dihydroxybenzoate, 4hydroxybenzoate, 4-hydroxyisophthalate or 1,2-dihydroxybenzene-3,5-disulphonate.

\section{DISCUSSION}

Our results are consistent with a pathway for 5-hydroxyisophthalate catabolism involving its hydroxylation to 4,5-dihydroxyisophthalate followed by decarboxylation to give protocatechuate as ring-fission substrate (Fig. 4). There was no evidence for initial decarboxylation followed by hydroxylation since the oxidation of 3-hydroxybenzoate by whole bacteria was very slow at first (Fig. 1) and no decarboxylation of 5-hydroxyisophthalate by bacterial extracts was observed. Indeed, the only substrate found for the decarboxylase was 4,5dihydroxyisophthalate, the compound also reported recently to be a product of a Streptomyces sp. (Endo et al., 1978). Neither of the other possible ring-fission substrates which could be formed by hydroxylation and decarboxylation reactions - gentisate or 2,3-dihydroxybenzoate - was oxidized by whole bacteria or extracts. Although whole bacteria also oxidized 4-hydroxyisophthalate and 4-hydroxybenzoate these were not substrates for the partially purified hydroxylase and were oxidized relatively slowly by bacterial extracts provided with NADPH (Fig. 2). This may be indicative of induction of a low level of a 4-hydroxybenzoate hydroxylase, as occurred in Pseudomonas putida when grown on 4hydroxyisophthalate (Elmorsi \& Hopper, 1977).

Both of the compounds, 4,5-dihydroxyisophthalate and protocatechuate, found in the medium during growth on 5-hydroxyisophthalate, were metabolized by whole bacteria (Fig. 1) and by extracts (Fig. 2), and the stoicheiometries (Table 1) are consistent with the pathway in Fig. 4 involving oxidation of protocatechuate by the ortho pathway (Ornston \& Stanier, 1966). Formation of protocatechuate by decarboxylation of 4,5-dihydroxyisophthalate in crude extracts under anaerobic conditions, which prevented further oxidation of the product, was demonstrated. There was no evidence for further decarboxylation to give catechol although this compound was oxidized by bacterial extracts. However, the rate was much less than that for protocatechuate.

The consumption of one extra molecule of oxygen in the metabolism of 5-hydroxyisophthalate by extracts (Table 1) and the requirement for reduced pyridine nucleotide (Fig. 2), with utilization of $1 \mu \mathrm{mol}$ per $\mu \mathrm{mol}$ substrate (Table 2), is as expected for hydroxylation by an enzyme, typical of several aromatic ring-hydroxylating mono-oxygenases that have been described (Flashner \& Massey, 1974). The product of this hydroxylation was identified, 


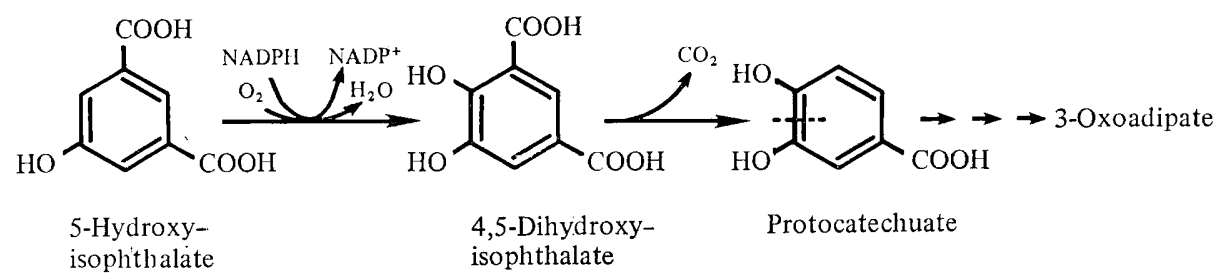

Fig. 4. Proposed pathway for the catabolism of 5-hydroxyisophthalate by strain $5 \mathrm{HI}$.

using hydroxylase separated from the decarboxylase, as 4,5-dihydroxyisophthalate. Separation of these two activities also rules out an oxidative decarboxylation of 5-hydroxyisophthalate to protocatechuate and in this respect it contrasts with protocatechuate formation from 4-hydroxyisophthalate by Pseudomonas putida which is carried out by a single enzyme (Elmorsi \& Hopper, 1977).

A similar non-oxidative decarboxylation occurs in the conversion of 2,3-dihydroxybenzoate to catechol by Aspergillus niger (Subba Rao et al., 1967), but a closer comparison can be made with the decarboxylation of 4,5-dihydroxyphthalate to protocatechuate in the pathway for phthalate metabolism in a Pseudomonas sp. (Ribbons \& Evans, 1960; Pujar \& Ribbons, 1976). The same pathway for phthalate metabolism to protocatechuate occurs in Pseudomonas testosteroni (Nakazawa \& Hayashi, 1977) and is probably also used by a number of other Gram-negative and Gram-positive organisms (Engelhardt et al., 1976). However, cleavage of protocatechuate in Pseudomonas testosteroni was by a 4,5-oxygenase whereas a 3,4-oxygenase was used by Ribbons' organism. The formation of 4,5-dihydroxyphthalate in these pathways appears to be catalysed by a dioxygenase inserting two hydroxyl groups simultaneously rather than by sequential hydroxylation with a monohydroxyphthalate as intermediate. Certainly 5-hydroxyisophthalate is not an intermediate in isophthalate metabolism by strain $5 \mathrm{HI}$, which was unable to oxidize this non-hydroxylated acid or to use it as a growth substrate. Although 5-hydroxyisophthalate has been reported as a natural product there is no information on its frequency of occurrence. However, the initial hydroxylase in strain $5 \mathrm{HI}$ was highly specific for this substrate.

We wish to thank Dr M. E. Rhodes-Roberts for help in microbiological tests and the Egyptian Government for a grant to E. A. Elmorsi to carry out these studies.

\section{REFERENCES}

Chapman, P.J. (1972). An outline of reaction sequences used for the bacterial degradation of phenolic compounds. In Degradation of Synthetic Organic Molecules in the Biosphere, pp. 17-55. Washington D.C.: Printing and Publishing Office, National Academy of Sciences.

Chapman, P. J. \& Hopper, D. J. (1968). The bacterial metabolism of 2,4-xylenol. Biochemical Journal 110, 491-498.

Elmorsi, E. A. \& HoPper, D. J. (1977). The purification and properties of 4-hydroxyisophthalate hydroxylase from Pseudomonas putida NCIB 9866. European Journal of Biochemistry 76, 197-208.

Endo, A., Kitahara, N., OKa, H., MiguchiFukazawa, Y. \& Terahara, A. (1978). Isolation of 4,5-dihydroxyisophthalic acid, an inhibitor of brain glutamate decarboxylase, produced by a Streptomyces species. European Journal of Biochemistry 82, 257-259.
ENGElhardT, G., WALlNöFER, P. R. \& RAST, H. G. (1976). Metabolism of $o$-phthalic acid by different Gram-negative and Gram-positive soil bacteria. Archives of Microbiology 109, 109-114.

Flashiner, M. S. \& MASSEY, V. (1974). Flavoprotein oxygenases. In Molecular Mechanisms of Oxygen Activation, pp. 245-283. Edited by O. Hayaishi. New York: Academic Press.

Gornall, A. G., Bardawill, C. J. \& David, M. M. (1949). Determination of serum proteins by means of the Biuret reaction. Journal of Biological Chemistry 177, 751-766.

Heilbron, I. (1965). Dictionary of Organic Compounds, 4th edn, vol. 3, p. 1706. London: Eyre \& Spottiswoode.

Hunt, S. E., IDris Jones, J. \& Lindsey, A. S. (1956). 4-Hydroxyisophthalic Acid. Journal of the Chemical Society, 3099-3107.

Mayer, F. L., Stalling, D. L. \& Johnson, J. L. 
(1972). Phthalate esters as environmental contaminants. Nature, London 238, 411-413.

Mitchell, F. L. \& Davies, R. E. (1954). The isolation and estimation of the steroid oestrogens in placental tissue. Biochemical Journal 56, 690-698.

Nakazawa, T. \& HaYashi, E. (1977). Phthalate metabolism in Pseudomonas testosteroni: accumulation of 4,5-dihydroxyphthalate by a mutant strain. Journal of Bacteriology 131, 42-48.

ORnston, L. N. \& StanieR, R. Y. (1966). The conversion of catechol and protocatechuate to $\beta$-ketoadipate by Pseudomonas putida. Journal of Biological Chemistry 241, 3776-3786.

Pujar, B. G. \& Ribbons, D. W. (1976). Purification of 4,5-dihydroxyphthalate decarboxylase and protocatechuate 3,4-oxygenase by affinity chromatography. Abstracts of the 76th Annual Meeting of the American Society for Microbiology, p. 145.

Ribbons, D. W. \& Evans, W. C. (1960). Oxidative metabolism of phthalic acid by soil pseudomonads. Biochemical Journal 76, 310-318.
Ronkarnen, P. (1963). Die Dünnschichtchromatographie der Ketosäuren. Journal of Chromatography 11, 228-237.

ROSENBERGER, R. F. \& ElsDen, S. R. (1960). The yields of Streptococcus faecalis grown in continuous culture. Journal of General Microbiology 22, 726-739.

RotHerA, A. C. H. (1908). Note on the sodium nitroprusside reaction for acetone. Journal of Physiology 37, 491-494.

Sistrom, W. R. \& Stanier, R. Y. (1953). The mechanism of catechol oxidation by $\mathrm{Myco}$ bacterium butyricum. Journal of Bacteriology 66, 404-406.

SмiтH, I. (1960). Chromatographic and Electrophoretic Techniques, 2nd edn, vol. 1. pp. 291-298. London: Heinemann (Medical Books).

Subba Rao, P. V., Moore, K. \& Towers, G. H. N. (1967). o-Pyrocatechuic acid carboxy-lyase from Aspergillus niger. Archives of Biochemistry and Biophysics 122, 466-473. 